\title{
PERKEMBANGAN \\ PENDIDIKAN DAN PERILAKU KEBERAGAMAAN PADA MASA KESULTANAN SAMBAS
}

\author{
Isyatul Mardiyati \\ STAIN Pontianak \\ e-mail: mardi_isya@yahoo.com
}

\begin{abstract}
From a historical perspective, Sambas Sultanate historically had a significant contribution to the diversity of the empire and the kingdoms in the archipelago. While the educational side of this empire have also contributed to the transmission of the scientific world-Malay archipelago in the context of the development of Islamic education as a chain of intellectual authority (intelctual geneology) which in turn result in the intensification of the Islamization of Islamic civilization in Indonesia. One role of the educational Sambas Sultanate is their success in producing the best sons of the Malay world and the Islamic world, such as Indra Crown Prince, Ahmad Khatib Sambas and H. M. Basyuni Imran. To find out more about the historical development of science Sambas Sultanate both from within and outside the palace will be presented further in this paper.
\end{abstract}

Dari perspektif sejarah, Kesultanan Sambas memiliki sumbangan yang signifikan terhadap keragaman kerajaan di kepulauan Indonesia. Sementara itu dari sisi pendidikan kerajaan ini juga memberikan kontribusi bagi transmisi dunia keilmuan di kepulauan Indonesia dalam konteks perkembangan pendidikan Islam sebagai jaringan intelektual (genealogi intelektual) yang pada gilirannya mempengaruhi intensifikasi Islamisasi peradaban Islam di Indonesia. Salah satu peran pendidikan Kesultanan Sambas adalah keberhasilannya dalam menghasilkan putra terbaik dalam dunia Melayu dan Islam, seperti Putra Mahkota Indra, Ahmad Khatib Sambas, dan H.M. Basyuni Imran. Kajian ini akan mengungkap perkembangan sejarah ilmu di Kesultanan Sambas, baik di dalam maupun luar Kesultanan Sambas.

Keywords: pendidikan, perilaku, keberagamaan, kesultanan Sambas 


\section{A. Pendahuluan}

Memahami proses transmisi keilmuan dunia Melayu¹-Nusantara, pada konteks perkembangan Islam merupakan hal yang sangat penting karena secara umum, sejauh menyangkut dunia Islam, wilayah ini dianggap sebagai daerah pinggiran (periphery), dan tidak termasuk ke dalam mainstream pemikiran global. Sehingga muncul adanya kecenderungan para peneliti tentang Islam untuk tidak menyertakan wilayah Melayu-Nusantara dalam berbagai diskusi mengenai Islam. Permasalahan ini disinyalir berasal dari berbagai persoalan akademis, terutama adanya stereotype pengamalan tradisi Islam Nusantara yang tidak sejalan dengan sumber aslinya. Bahkan, Islam di wilayah ini tidak jarang dianggap sebagai bentuk Islam yang "tidak orisinil", atau berbeda dengan Islam di Timur Tengah sebagai "pusat"nya.

Islam di Indonesia pada dasarnya memiliki corak yang khas. Kekhasan ini dapat dilihat dari akulturasi pengamalan ajaran agama dengan kebudayaan lokal. Alur transmisi Islam di Nusantara merupakan bentuk pemahaman dari rekonsiliasi pemikiran masyarakat Melayu-Indonesia melalui penetrasi gagasan. Hal ini merupakan bentuk mata rantai otoritas intelektual (intelctual geneology) yang pada gilirannya menghasilkan intensifikasi proses Islamisasi peradaban.

Dari sisi kultural, proses adaptasi ini tidak dapat dipungkiri dengan adanya keterlibatan ulama yang menyebarkan ajaran agama, namun disisi lain, faktor politik penguasa di daerah lokal secara jelas turut berperan dalam kronologis penetrasi agama di masyarakat. Begitu pula halnya dengan Kesultanan Sambas yang sebelum kerusuhan berbau sara tahun 1999 belum mendapat porsi yang signifikan, tetapi setelah mata dunia keilmuan melirik lebih dalam terhadap eksistensi kemajuan edukasi pada saat kejayaannya. Maka akan menjadi sebuah pembahasan menarik mengenai perspektif kebudayaan lokal dan simbiosisnya terhadap penyebaran agama.

\footnotetext{
${ }^{1}$ Kata "Melayu" (Malay) menurut Ronald berakar dari kata "Layu" (yaitu bahasa Melayu Johor: Layar, dan Melayu Minang: Layo) yang berarti berlayar. Selain itu juga kata melayu dapat diartikan sebagai Layu/berkerut (shriveled) atau disalai/diasapi (smoked). Lihat Ronald Provencher, Islam in Malaysia and Thailand, dalam Raphael Israeli, ed., The Crescent in The East, Islam in Asia Major, (USA: Curzon Press-London \& Humanities Press-NJ, 1982), p. 142.
} 


\section{B. Perkembangan Pendidikan dan Perilaku Keberagamaan}

\section{Latar Belakang}

Sebagaimana telah disebutkan, umat Muslim yang ada di Indonesia memiliki corak khas. Hal ini ditinjau dari pengamalan ajaran agama yang dilakukan sehari-hari. Adalah sebuah realitas bahwa Islam di Nusantara tidak menolak adanya pengaruh lokal, tetapi untuk menyebut tradisi Islam di Nusantara tidak mempunyai kaitan dengan Islam di Timur Tengah merupakan kekeliruan yang amat fatal..$^{2}$ Hubungan antara kaum Muslim MelayuIndonesia dan Timur Tengah telah terjalin sejak masa-masa awal Islam. Hal ini terbukti dari adanya pedagang Muslim yang berasal dari Arab, Persia dan Anak benua India mendatangi kepulauan Nusantara, tidak hanya dalam kapasitas berdagang, melainkan juga untuk menyebarkan Islam kepada penduduk setempat. Penetrasi Islam di masa lebih belakangan nampaknya lebih dilakukan para guru sufi yang sejak akhir abad ke-12 datang dalam jumlah yang semakin banyak ke Nusantara. ${ }^{3}$

Ada beberapa kesulitan untuk membuktikan kapan masuknya Islam di Nusantara, ${ }^{4}$ khususnya di Sambas. Hal ini disebabkan kurangnya bukti-bukti otentik yang dapat menunjukkan masuknya Islam. Pada umumnya sumber yang digunakan sebagai dasar argumen penyebaran Islam pertama adalah sumber yang berbentuk artefak dan teks historiographi tradisional. Yang pertama, biasanya pelacakan hanya mengandalkan pada sumber-sumber yang telah banyak ditulis oleh para arkeolog. Sedangkan yang kedua mendasarkan pada telaah teks-teks klasik.

\footnotetext{
${ }^{2}$ Azyumardi Azra, Jaringan Ulama Timur Tengah dan Kepulauan Nusantara Abad XVII dan XVIII: Melacak Akar-akar Pembaharuan Pemikiran Islam di Indonesia, (Bandung: Mizan, 1998), h. 16; Lihat juga Clifford Greetz, The Religion of Java, (New York: Free Press, 1960), p. 17.

${ }^{3}$ Ibid, h. 17.

${ }^{4}$ Penyebaran Islam ke tanah Indonesia dilakukan para pedagang Muslim dari Arab, sejak abad ke-7 Masehi, saat pelabuhan-pelabuhan dagang Nusantara ini dikunjungi oleh para pedagang asing, termasuk para saudagar Arab tersebut. Strategi penyebaran Islam lewat jalur perdagangan ini sangat efektif menembus jantung kekuasaan politik, karena Raja serta kelompok elit penguasa elit lainnya merupakan para pelaku usaha perdagangan, pemilik kapal atau saham dalam usaha angkutan laut tersebut. Abuddin Nata, Sejarah Kebudayaan Islam-II. (Jakarta: Direktorat jendral Pembinaan Kelembagaan Agama Islam dan Universitas Terbuka, 1996), h. 531.
} 


\section{Perkembangannya Kesultanan Sambas}

Kesultanan Sambas pertama kali di dirintis oleh raja Tengah, ayah dari Sultan Sambas yang pertama yakni, Raden Sulaiman degan gelar Sultan Muhammad Syafiuddin sekitar tahun 1620 M. Mengenai Kesultanan Islam Sambas sendiri, secara resmi ditandai dengan diangkatnya Raden Sulaiman (1631-1688) sebagai sultan yang pertama, meskipun sejak awal tahun 1600an Islam telah berkembang di Sambas selama 312 tahun.

Apabila ditinjau berdasarkan naskah Salsilah ${ }^{5}$ Kerajaan Sambas justru didirikan pada tanggal 10 Dzulhijjah tahun 1040. Namun ada pula yang menyebutkan bahwa Kesultanan Sambas berdiri pada tahun 1612 seperti yang diungkap oleh Machrus Effendy atau ada juga yang mengatakan tahun 1622, seeta tahun 1931 bagi mereka yang mengutip pendapat seorang sejarawan Melayu bernama Awang al-Sufri dari Brunei.

Kesultanan Sambas dikategorikan sebagai Kesultanan Melayu yang terletak di sebelah utara pulau Borneo dengan letak ibu kota yang berada di Muara Ulakan dengan posisi menghadap tiga cabang anak sungai, yakni; sungai Sambas, sungai Teberau, dan Sungai Subah. Di ujung utara istana yang dikenal dengan sebutan al-Wadhauq Hubbillāh (artinya citarasa cinta Allah) tampak gunung Senujuh yang berbentuk melengkung, dengan sebelah timurnya berderet satu barisan bukit yang dinamakan pegunungan Sebedang. Apabila di lihat sisi muara sungai Sambas, yaitu bagian arah selatan akan terlihat dua buah gunung yang mengapit, yaitu gunung Gajah dan gunung Kalangbau. Posisi inilah yang menjadikan ibu kota dan istana Kesultanan Sambas kala itu disebut dengan "Negeri laksana bunga kembang setaman".

\section{Asal Usul Silsilah Keturunan Penguasa Sambas}

Asal usul penguasa Sambas termaktub dalam naskah "Asal Raja-raja Sambas", berisi tentang silsilah keturunan raja-raja Sambas Tua yang ber-

5 Naskah Salsilah atau Salasalah ditulis langsung oleh Raden Affiudin atau Raden Arifin bin Tajuddin Sultan Sambas ke-13 yang bergelar Sri Paduka Sultan Muhammad Syafiyudin II. Selain itu ia juga digelari Marhum Cianjur, hal ini terkait karena Raden Affiudin pernah menimba ilmu di tanah Padjajaran tepatnya daerah Cianjur (saat ini merupakan salah satu Kabupaten di Jawa Barat). Naskah ini juga tercatat ditulis pada malam Jum'at tanggal 14 Ramadhan $1312 \mathrm{H}$ bersamaan dengan tanggal 14 Desember $1903 \mathrm{M}$. 
kuasa di kota lama. Naskah ini pula memuat raja kerajaan Balai Pinang di Selakau, serta cerita perjalanan Raja Tengah ${ }^{6}$ dari Brunei yang hendak berdiam di Gelagak selama dua tahun dan selanjutnya menetap di Matan Sukadana akibat berselisih dengan saudaranya Sultan Abdul Jalil Jabbar. ${ }^{7}$

Secara rinci silsilah Raja Sepundak (Raja Sambas Tua) yang diungkapkan dalam naskah ini, adalah sebagai berikut:

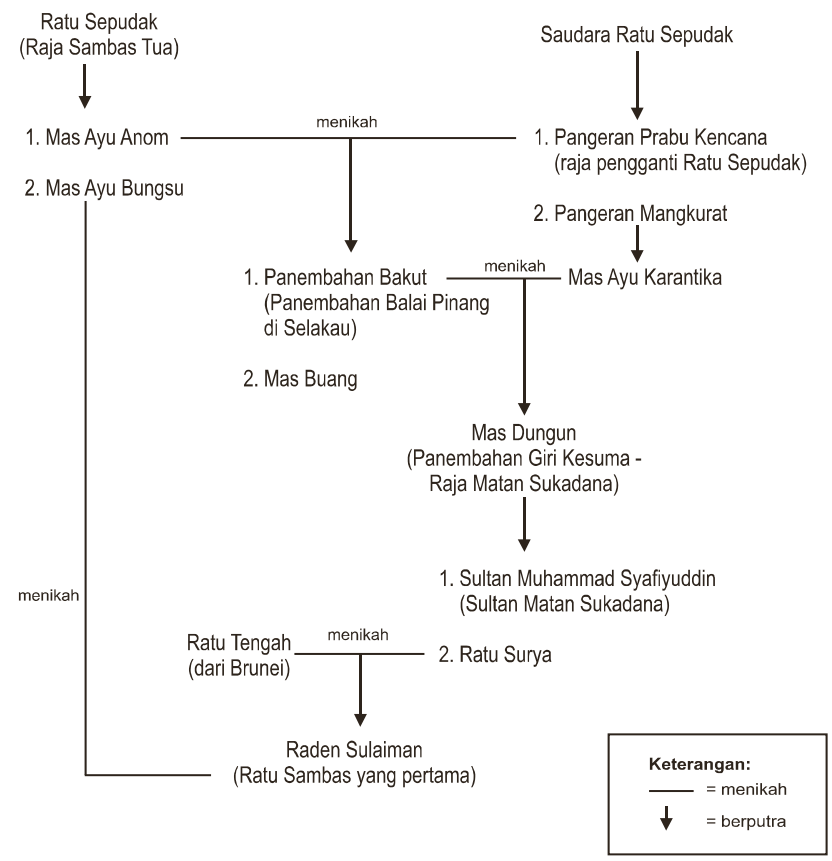

\section{Gambar 1.}

Silsilah Penguasa Sambas

Sumber: Pabali H. Musa (2003: 125)

${ }^{6}$ Raja Tengah dalam naskah Asal Raja-raja Sambas diceritakan tewas akibat ditikam oleh seorang sakit 'gila' ketika hendak buang hajat di wilayah Batu Buaya, Kuala Sentubung, dalam perjalanannya menuju Serawak.

7 Diceritakan bahwa Raja Tengah adalah seseorang yang gagah perkasa, pemberani dan cerdas. Gerak geriknya gesit sehingga sepak terjangnya tidak dapat sepenuhnya didikte oleh pihak Istana kerajaan Brunei kala itu. Keadaan ini membuat saudara kandung tertuanya, yaitu Sultan Abdul Jalil Jabbar yang berkuasa merasa segan sekaligus khawatir karena Raja Tengah dapat menjadi pesaingnya. Oleh karena itu, hal ini disiasati sang Sultan agar adiknya (Raja Tengah) mau untuk menjadi penguasa di wilayah lain (Serawak). 
Bagian awal Salsilah mengemukakan silsilah para Sultan yang berkuasa di Brunei Darussalam. Menurut naskah ini diceritakan bahwa pada masa itu Kerajaan Brunei masih memeluk agama Hindu dan berada di bawah koloni Kerajaan Majapahit yang berpusat di pulau Jawa. Untuk itulah maka setiap tahun penguasa Brunei mengantarkan upeti kepada raja Majapahit berupa satu tempayan (gentong) air pinang muda sebagai bukti ketundukan dan kesetiaan. Namun setelah Batara Majapahit dan Patih Gajah mada meninggal dan kekuasaan Majapahit pun mulai melemah seiring konflik intern kerajaan, maka kerajaan Brunei melepaskan diri dari daerah kekuasaan Majapahit.

\section{Struktur Organisasi Kerajaan}

Kelembagaan pemerintahan Islam terbentuk di Sambas setelah datingnya Raja Tengah yang merupakan seorang Muslim. Kemudian seiring waktu maka adik ipar dari Sultan Muhammad Syafiuddin yang sebelumnya bernama Panembahan Giri Mustika raja di Sukadana masuk Islam dengan bimbingan seorang ulama yang di utus Raja Makkah. Dari Syekh Syamsuddin ini pula Raja Tengah mendalami berbagai pengetahuan keagamaan.

Pada perkembangan selanjutnya Raja Tengah dikawinkan oleh Sultan Muhammad Syafiuddin dengan adiknya yang bernama Ratu Surya Kesuma. Dari perkawinan tersebut Raja Tengah memperoleh lima orang anak yang diantaranya bernama Raden Sulaiman, Raden Badaruddin, Raden Abdulwahab, Raden Rasymi Putri dan Raden Ratnawati. Dari pernilahan inilah Raja Tengah bersama isterinya Ratu Surya Kesuma dan lima orang anaknya menghadap Sultan Muhammad Syafiuddin, untuk berlayar meninggalkan Sukadana ke Sambas atau kota Bangun ketika itu.

Perjalanan Raja Tengah berlayar ke Sambas diikuti oleh prajurit dengan mempergunakan empat puluh buah kapal yang dipersenjatai. Rombongan Raja Tengah menyusuri pantai utara, lalu memasuki sungai Sambas Besar, berhenti pada suatu tempat bernama Kota Bangun, di tempat tersebutlah mereka pertama kali membangun perkampungan baru. Tempat perkampungan baru itu tidak jauh dari Kota Lama Ibukota kerajaan Sambas yang diperintah oleh Ratu Sepudak sekarang atau Kecamatan Teluk Keramat. Hubungan yang terbina dengan baik antara dua penguasa itulah yang kemudian terikat dalam sebuah ikatan pernikahan antara putra Raja Tengah 
yang pertama Raden Sulaiman dengan Putri Mas Ayu Bungsu, yang merupakan putri kedua Ratu Sepudak.

\section{Karya-karya Keilmuan}

Karya-karya ilmiah pada masa kekuasaan Kesultanan Sambas tidaklah terlalu banyak jika dibandingkan dengan kerajaan-kerajaan Nusantara lainnya yang bercorak Melayu. Hal ini disebabkan berbagai persoalan baik letak geografis kerajaan Sambas yang sulit ditempuh dalam waktu singkat, maupun karena faktor politik dan ekonomi di mana pada masa itu penjajah kolonial Belanda menekankan perkembangan dan kemajuan lebih ditekankan di wilayah kepulauan Jawa. Meskipun demikian ada beberapa karya ilmiah di berbagai bidang yang tercatat dalam sejarah perkembangan Kesultanan Sambas khususnya pada masa kekuasaan Maharaja H. Muhammad Basyuni Imran, dimana ketika itu Kesultanan Sambas berada di puncak kejayaannya. Adapun beberapa karya tersebut antara lain:

1. Kitab Nur al-Sirāj fi Qișșah al-Isrā' wa '-Mi'rāj (Cahaya Pelita pada Ceritera Isra' dan Mi'raj). Kitab setebal 26 halaman ini kemudian direvisi pada hari Jum'at, 19 Agustus 1938/23 Jumadil Akhir 1357 ditulis dengan huruf "Jawi" (Arab Melayu).

2. Pada tanggal 27 Maret 1918/13 Jumadil Awwal 1336, Maharaja Imam M. Basyuni Imran menulis kitab Bidāyat al-Tawhïd fi 'Ilm al-Tawhïd (Dasardasar keesaan Allah dalam Ilmu Tauhid). Kitab setebal 59 halaman ini dicetak oleh penerbit al-Ahmadiyah Singapura pada tahun yang sama.

3. Maharaja Imam M. Basyuni Imran menulis risalah al-Tadzkīrat Bādi'ah fi Ahkāmil Jum'ah (Peringatan bagi yang Mengada-ada dalam Hukum Shalat jum'at). Tulisan ini merupakan kelanjutan risalah Manhal, ditulis dalam bahasa Arab dan selesai ditulis pada 17 Muharram 1339 H / 1920 M.

4. Pada tanggal 14 Oktober 1920/22 Safar 1339, Maharaja Imam M. Basyuni Imran menulis risalah Cahaya Suluh, Pada Mendirikan Jum'at Kurang Daripada Empat Puluh. Risalah ini dicetak pada tahun yang sama di percetakan al-Ikhwan, Singapura.

5. Kitab al-Nușuṣ wa'l-Barāhin 'alā Iqāmat al-Jum'ah bimā Dān al-Arba 'in (Beberapa Dalil dan Argumentasi dalam Melaksanakan Shalat Jum'at 
yang Kurang dari Empat Puluh Orang), karya Maharaja Imam M. Basyuni Imran dicetak oleh percetakan al-Manar, Kairo. Karya ini merupakan edisi bahasa Arab dari risalah Cahaya Suluh.

6. Pada tanggal 3 September 1930 /9 Rabiul Awwal 1349, Maharaja Imam Maharaja Imam M. Basyuni Imran menulis kitab Tadzkïr, Sabīl al-Najāh fi Tārik al-șalāh (Jalan Kelepasan pada Mengingati Orang yang Meninggalkan Sembahyang). Kitab ini dicetak oleh percetakan al-Ahmadiyah, Singapura, pada tahun 1931.

7. Pada tanggal 18 Januari 1931/29 Sya'ban 1349. Maharaja Imam M. Basyuni Imran menulis Kitab Khulasah Sirāh al-Muhammadiyah, kitab sejarah karangan Muhammad Rasyid Ridha. Basyuni Imran menambahkan kata-kata Hakikat Seruan Islam pada judul terjemahnya setebal 89 halaman ini dicetak oleh percetakan al-Ahmadiyah, Singapura.

8. Pada tanggal 21 Januari 1934/5 Syawal 1352, Maharaja Imam M. Basyuni Imran menulis kitab Irsyād al-Ghilmān fi Adab Tilāwat al-Qur'ān (Petunjuk Praktis untuk anak tentang Adab Membaca al-Qur'an). Kitab ini diterbitkan dan dicetak pada percetakan al-Ahmadiyah Singapura.

9. Pada tanggal 18 Oktober 1935/20 Rajab 1354, Maharaja Imam M. Basyuni Imran menulis kitab Durūs al-Tawhïd (Pelajaran-pelajaran tentang Tauhid). Kitab ini kemudian diterbitkan dan dicetak pada percetakan al-Ahmadiyah Singapura.

10. Kitab Husn al-Jawāb 'an Isbāt al-Ahillah bi 'l-Hisāb (Molek Jawaban tentang Menetapkan Awal Bulan dengan Metode Hitungan), karya Maharaja Imam M. Basyuni Imran dicetak di Penang, Malaysia.

11. Maharaja Imam M. Basyuni Imran menulis kitab al-Janaiz. Kitab kecil ini ditulis di Sambas pada masa pemerintahan pendudukan Jepang. kalender Jepang: 21 Sigitsu 2603.

Dari berbagai tulisan maupun kitab yang ada tersebut, masih ada beberapa kitab dan tulisan lain yang ditulis oleh beberapa ulama maupun para bangsawan Kesultanan Sambas seperti kitab yang ditulis Ahmad Khatib Sambas, Pangeran Indra Mahkota dan sebagainya. Namun banyak pula dari tulisan-tulisan tersebut yang hilang keberadaannya atau mungkin ada yang menjadi copy-file di Kerajaan Belanda. Mengingat ketika itu pemerintah Belanda berhasil menaklukkan Kesultanan Sambas. 


\section{Mata Rantai Keilmuan Abad Pra-Reformis Maharaja H. M. Basyuni}

Sepanjang sejarahnya, Kesultanan Sambas turut berperan dalam melahirkan putra-putra terbaik bagi dunia Melayu dan dunia Islam, diantara mereka adalah Pangeran Indra Mahkota, Ahmad Khatib Sambas dan H. M. Basyuni Imran. Pada pertengahan abad ke-18 di Sambas lahir seorang putra bernama Mohammad Sholeh (kelak di kenal dengan sebutan Pangeran Indra Mahkota) dari pasangan Pangeran Syarifuddin bergelar Pangeran Sharmayudha asal Brunei dan Putri Kencana binti Raden Jamak bin Raden Marhum Bungsu (Sultan kelima Sambas yang bergelar Sultan Aqmadin II. Pada masa itu Mohammad Sholeh merupakan seorang bangsawan yang cerdas, bahkan ia disekolahkan di Batavia (saat ini Jakarta) dan berhasil menamatkan pendidikan di OSVIA. Berkat prestasinya ini pula beliau di beri kesempatan untuk melanjutkan studinya ke Belanda.

Sekembalinya dari Belanda Pangeran Mohammad Sholeh dipercaya oleh Sultan yang berkuasa untuk mengatur Perlembagaan Hal Ihwal Dalam Negeri (semacam Departemen Dalam Negeri) dan menjalin hubungan kembali dengan negeri Brunei. Baru sekitar tahun 1824 Sultan Brunei Mohammad Tajuddin Kanzul Alam menobatkannya sebagai gubernur Serawak dengan gelar Pangeran Indra Mahkota.

Selanjutnya pada masa ini pula muncul ulama Sambas yang terkenal, yaitu Syekh Ahmad Khatib Sambas ${ }^{8}$ (1802-1875) seorang ulama sekaligus pemimpin tarekat yang sebenarnya juga merupakan sarjana keilmuan Islam. Dalam catatan Snouck Hurgronje dapat diketahui bahwa Ahmad Khatib Sambas muda pernah belajar dengan Syekh Daud bin Abdullah al-Fatani dan Syekh Samsuddin di Makkah.

Adapun kontribusi Ahmad Khatib Sambas dalam transmisi keilmuan Islam, yakni dari ilmu tasawuf dalam karya tulisnya Fath al-Ārifin sebuah

8 Dalam catatan lain Syekh Ahmad Khatib Sambas lahir di Kampung Dagang Sambas pada tahun 1803. Beliau adalah salah seorang ulama yang berhasil memadukan dua metode spiritual besar yakni tarekat Qadiriyah dan tarekat Naqsabandiyah menjadi satu metode spiritual baru yang diakui dunia Islam. 
tulisan populer dalam praktek sufi di dunia. Dengan hadirnya tokoh sekaliber ulma Ahmad Khatib inilah penguasa ke-8 Kesultanan Sambas, Muruhum Anom yang bergelar Sultan Muhammad Ali Tsafiuddin (1813-1826), mulai membangun institusi keagamaan Islam di istana dengan melantik H. Nuruddin Mustafa sebagai Imam Kesultanan.

Dari institusi Kesultanan inilah kemudian pada perkembangan selanjutnya, metode pendidikan di ditekankan pada kalangan keluarga, pembesar dan Petinggi kerajaan. Setelah itu barulah mata rantai keilmuan di Kesultanan menyebar secara estafet ke luar lingkup istana. Hal ini tentu tanpa masalah berarti, mengingat Kesultanan yang berkuasa memiliki pengaruh yang besar dalam politik, ekonomi maupun di bidang sosial kultural masyarakat Sambas. Dari lembaga pendidikan istana (palace school) ini pula yang kemudian menjadi cikal bakal dari Madrasah al-Sultaniyah, yaitu madrasah pertama di Sambas meski kurikulum madrasah yang ada ketika itu masih terbatas pada pelajaran Agama Islam dan peserta didiknya pun masih berasal dari kalangan keluarga Kesultanan.

Adapun gambar mata rantai keilmuan ini dapat digambarkan sebagai berikut:

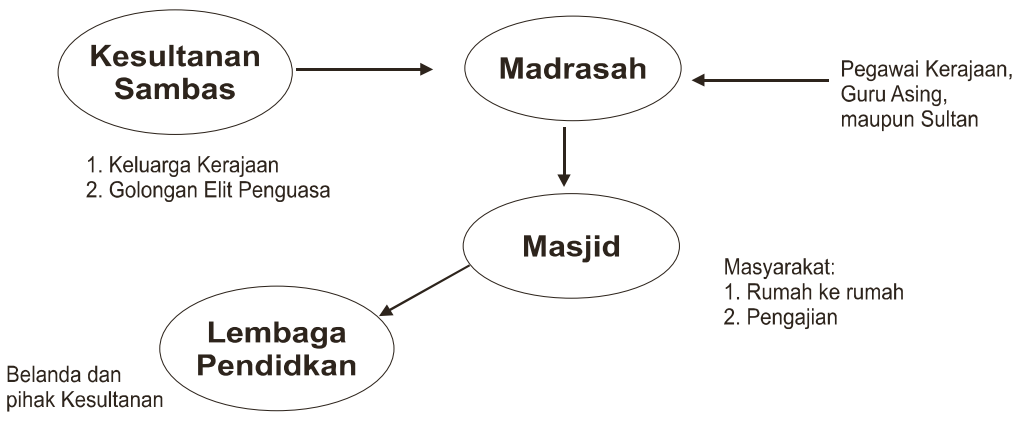

Gambar 2.

Mata Rantai Keilmuan di Sambas

Adapun orang yang berjasa dalam kesultanan Sambas di dalam mendirikan madrasah al-Sultaniyah pada tahun 1868 tersebut adalah Muhammad Tsafiuddin II. Kemudian pada perkembangan selanjutnya barulah H.M. Basyuni Imran, Ahmad Fauzi dan Abdurrahman Hamid mengembangkan 
prospek sekolah tersebut ke arah pendidikan modern. namun di sisi lain, kebijakan pemerintah kolonial yang hendak mempertahankan eksistensinya di tanah Kalimantan, mendirikan sekolah desa (volkschool) pada sekitar akhir abad ke-19. ide mempertahankan eksistensi inilah yang kemudian secara langsung maupun tidak langsung menggeser orientasi madrasah al-Sultaniyah yang mengajarkan kitab-kitab kuning menambahkan materi pelajaran umum seperti membaca, berhitung dan menulis huruf Latin. Disinilah awal dikotomi pendidikan di Sambas yakni pendidikan oleh dan untuk kepentingan Kerajaan Belanda versus pendidikan yang disusun dari gabungan intimidasi kepentingan Kerajaan Belanda dengan idealisme Kesultanan Sambas. ${ }^{9}$

\section{E. Pendidikan di Sambas Awal Abad ke-20}

\section{Otoritas Maharaja H. M. Basyuni Imran dalam Bidang Pendidikan}

Kesultanan Sambas mencapai puncak kebesarannya pada awal abad ke20 dengan citranya sebagai "Serambi Mekkah" kemajuan ini dicirikan dengan pengembangan keilmuan Islam dengan corak reformisme yang digulirkan pada masa kekuasaan Maharaja H. Muhammad Basyuni Imran (1885-1976) putra dari H. Muhammad Imran.

Menurut G.F. Pijper, H. Maharaja H. Muhammad Basyuni Imran "betulbetul mewakili pandangan reformisme Mesir di Indonesia”. Hal ini karena. H. Muhammad Basyuni Imran termasuk seorang ahli agama terkemuka yang menata bingkai pemikiran sosial-kultural keberagamaan di Sambas. Tidak mengherankan paradigma pemikirannya dianggap memiliki universalisme keilmuan, yaitu sikap menghargai semua khazanah ilmu pengetahuan, termasuk ilmu agama.

Universalisme keilmuan inilah yang menjadikan Maharaja Sambas yang satu ini tidak terjebak pada fanatisme sempit suatu aliran pemikiran dalam Islam. Dalam bidang aqidah misalnya, beliau tidak hanya berpegang kepada faham Asy'ariyah yang cenderung fatalistik, melainkan juga memegang faham

${ }^{9}$ Lihat Dinamika Pendidikan Pesantren karya Mastuhu sebagai perbedaan pendidikan di Jawa masa kolonial dengan masa Kesultanan Sambas. 
Maturidiyah yang memberikan kekuatan lebih besar kepada manusia dalam menentukan perbuatannya.

Sedangkan di bidang Fiqh pemikiran dan faham hukum keagamaan, $\mathrm{H}$. Muhammad Basyuni tidak semata-mata mengikuti secara kaku mazhab Syafi'iyah, melainkan juga berbagai pendapat lintas mazhab dan lintas ulama. Meskipun struktur kultural yang terbentuk dalam dirinya adalah seorang Ahlus-Sunnah dan mazhab Syafi'i. Pada tataran praksis, dalam mengajarkan ilmu agama Basyuni Imran cenderung menggunakan metode terutama gagasan pembaruan yang dikembangkan oleh jurnal al-Mannar seperti telah disinggung di muka. Sedangkan dalam mengajarkan ilmu umum ia cenderung menggunakan kurikulum Barat yang dikembangkan oleh pendidikan kolonial (Belanda). Maharaja H. M. Basyuni Imran memang tidak memberikan definisi secara khusus tentang pendidikan. Dalam hal ini yang menjadi penekanannya adalah mengajar maupun belajar merupakan ibadah untuk mencari rida Allah. Oleh karena itu seorang pendidik terlebih dulu meluruskan niat. Ia harus tulus dalam mencari rida Allah. Tidak bermaksud mencari keuntungan atau pujian orang. Pada bagian lain ia menyebut seorang yang ikhlas akan bekerja dengan perasaan lapang. Ia tidak mudah mengeluh dalam menghadapi kesulitan. Ia bekerja hanya karena Allah.

Selain itu, dalam upaya meningkatkan dan mengembangkan kegiatan penyuluhan umat. Dalam hal ini beliau mengirim petugas penyuluh (juru dakwah) atau yang lebih dikenal dengan sebutan "Guru Tabligh" ke desadesa. Selain itu beliau sendiri selalu mengadakan ceramah umum (tashwïr) di Masjid Jami' Kampung Dalam Kaum pada hari jum'at yang dilaksanakan sekitar satu jam sebelum pelaksanaan shalat Jum'at. Selain itu pengajian ibuibu atau kaum perempuan pada setiap selesai shalat Jum'at dengan tempat pelaksanaannya di rumah beliau. Hal lain yang menarik dari metode penyebaran mata rantai keilmuan $\mathrm{H}$. Muhammad Basyuni, yakni dilaksanakannya pula pengajian-pengajian intensif atau diskusi rutin yang dilaksanakan dari rumah ke rumah. Adapun substansi materi yang disampaikan dalam pengajian ini pada umumnya lebih menekankan pada aspek-aspek ibadah serta masalah-masalah keagamaan dan keumatan.

Dalam bingkai tersebut, ada tiga corak pemikiran yang dikembangkan oleh H. Muhammad Basyuni Imran, yaitu mengenai reformisme, tradisionalisme dan neo-sufisme dalam kurun waktu 33 tahun atau pada usia muda di 
tahun 1912 sampai pada tahun 1945. Jika terdapat suatu masalah yang tidak dapat diselesaikan atau tidak ditemukan pemecahannya, maka beliau akan langsung menanyakannya kepada redaktur majalah al-Manār di Kairo yang dipimpin oleh Muhammad Rasyid Ridha. Diantara berbagai persoalan yang dimintakan jawabannya kepada Muhammad Rasiyd Ridha adalah: mengapa orang-orang Islam mundur dan mengapa orang-orang selain mereka maju? Bolehkan mentalqinkan orang-orang yang sudah meninggal? Dan lain-lain.

Adapun salah satu bukti otentik pelaksanaan kegiatan pendidikan dan keagamaan yang dilakukan H. Muhammad Basyuni, terekam dalam sebuah surat beliau untuk Rasyid Ridha sebagaimana dikutip G.F. Pijper dalam Pabali H. Musa (2003):

"Segala puji bagi Allah (Alhamdulillah)! Walaupun saya telah meninggalkan guru-guru saya, juga telah meninggalkan bangku sekolah di Dar al-Dakwah wal-Irsyad, saya tetap tanpa henti-hentinya mendalami kitab-kitab Imam Syafi'i, kitab-kitab Mazhab lain kitab-kitab tafsir Qur'an dan Hadits, terutama Tafsir al-Manār, majalah al-Manār, dan juga kitabkitab lain tentang bermacam-macam ilmu pengetahuan. Untuk meningkatkan kemampuan saya, maka saya pun melatih diri dengan menulis kitab-kitab atau risalah-risalah dalam bahasa Indonesia maupun bahasa Arab, juga mengajukan pertanyaan tentang soal-soal agama, lewat surat kepada Sāhib al-Manār [Rasyid Ridha], pada waktu itu dia masih hidup. Dan saya membaca tafsir, hadits atau sesuatu yang lain pada hari jum'at di Masjid Jami' Sambas atau kadang-kadang di masjid lain Sambas."

Reformisme yang dilakukan oleh Maharaja Imam Sambas ini ditunjukkan kepada pemurnian ajaran Islam (puritanisasi, tajdīd), mengembangkan (modernisasi, iṣlāhh) institunsinya, dan pengembangan kehidupan keduniaan umat Islam Sambas.

Berkenaan dengan pemurnian ajaran Islam H. Muhammad Basyuni bersikap tegas terhadap berbagai penyimpangan baik di bidang aqidah, ibadah dan hukum. Menurut beliau, agama Islam memberikan pengertian kepada pemeluknya tentang aqidah, ibadah dan dan segala hal yang halal dan haram menurut batasan-batasan yang ditentukan oleh Allah. Namun kenyataannya di dalam tiga aspek tersebut justru banyak yang telah dicemari dan diselewengkan oleh berbagai bid'ah. Bid'ah di bidang aqidah muncul dalam bentuk khufarat dan takhayul. Seperti menganggap makhluk tertentu memiliki sifat ketuhanan dan dianggap sebagai Tuhan, ayat-ayat al-Qur'an 
dijadikan Azimat atau dijadikan obat-obatan bahkan ada yang dikomersilkan di perkuburan. Bid'ah di bidang agama (ibadah khusus) terlihat pada pergantian atau mengubah ketentuan-ketentuan ibadah dengan caranya sendiri. Bid'ah di bidang hal dan haram seperti menghalalkan sesuatu yang haram atau mengharamkan suatu yang halal yang sudah jelas ketentuannya di dalam hukum Allah SWT. Menurut H. Muhammad Basyuni, bid'ah-bid'ah tersebut banyak sumbernya, diantaranya yang berasal dari hawa nafsu, fanatisme, dan berbagai tujuan dari keduanya. Beliau meyakini bahwa penyelewengan terhadap al-Qur'an terjadi karena fanatisme mazhab. Karena itulah bid'ah senantiasa melahirkan perpecahan.

Adapun beberapa peristiwa penting dalam catatan historis yang menjadi kesimpulan napak tilas $\mathrm{H}$. Muhammad Basyuni dapat dilihat pada tabel berikut:

Tabel 1.

Napak Tilas Peristiwa Penting dalam Sejarah Kerajaan Sambas (H. Muhammad Basyuni Imran)

\begin{tabular}{|c|c|c|}
\hline No. & Tahun & Peristiwa \\
\hline 1 & 1885 & (16 Oktober) Muhammad Basyuni Imran dilahirkan di Sambas. \\
\hline \multirow{2}{*}{2} & \multirow{2}{*}{1890} & $\begin{array}{l}\text { (8 Desember) Raden M. Ariadiningrat melanjutkan pelajaran di Opleiding } \\
\text { School Voor Indianche Ambtenaar (OSVIA) Serang, Jawa Barat, setelah } \\
\text { menamatkan pendidikan di sekolah partikulir (swasta) Sambas. }\end{array}$ \\
\hline & & $\begin{array}{l}\text { Sultan Muhammad Syafiuddin II menerima penghargaan bintang } \\
\text { Bahaderi Singa Nederland (Rider in de orde van den Nederlansche } \\
\text { Indie Leeuw) dari Raja William III. }\end{array}$ \\
\hline 3 & 1894 & $\begin{array}{l}\text { (12 Maret) Raden M. Ariadiningrat pulang ke Sambas dari } \\
\text { melanjutkan pelajaran di OSVIA Serang, Jawa Barat. }\end{array}$ \\
\hline \multirow[t]{2}{*}{4} & 1895 & $\begin{array}{l}\text { Raden M. Ariadiningrat diangkat menjadi guru bantu di sekolah } \\
\text { partikulir di Sambas. }\end{array}$ \\
\hline & & $\begin{array}{l}\text { Syekh Nurdin Tekarang wafat. Lantaran kealimannya, masyarakat } \\
\text { setempat lebih populer menyebut makamnya Keramat Tekarang. }\end{array}$ \\
\hline \multirow{2}{*}{5} & \multirow{2}{*}{1902} & $\begin{array}{l}\text { (5 April) Raden M. Ariadiningrat diangkat menjadi anggota } \\
\text { Pengadilan (Landraad) di Sambas. }\end{array}$ \\
\hline & & $\begin{array}{l}\text { Muhammad Basyuni Imran belajar di Makkah selama } 5 \text { (lima) tahun } \\
\text { (1902-1907). }\end{array}$ \\
\hline 6 & 1903 & $\begin{array}{l}\text { (9 September) Sultan Muhammad Syafiuddin II mendirikan sebuah sekolah } \\
\text { "Bumi Putra"kelas dua untukmembuka kesempatan belajar bagi rakyatnya. }\end{array}$ \\
\hline
\end{tabular}




\begin{tabular}{|c|c|c|}
\hline & & $\begin{array}{l}\text { (4 Desember = } 14 \text { Ramadan 1321) Sultan M. Syafiuddin II menulis } \\
\text { Risalah Silsilah Kerajaan Sambas" yang memuat sejarah asal usul } \\
\text { Kesultanan Sambas sejak dari keturunan Sultan Brunei, riwayat } \\
\text { Sultan Tengah, Sultan M. Syafiuddin I, dan Sultan Muhammad } \\
\text { Tajuddin. }\end{array}$ \\
\hline & & $\begin{array}{l}\text { (31 Desember) Raden M. Ariadiningrat diangkat sebagai Wakil Sultan } \\
\text { di Singkawang bergelar Pangeran Tumenggung Jaya Kesuma Negara. }\end{array}$ \\
\hline 7 & 1904 & Komplek makam Sultan M. Syafiuddin II dibangun. \\
\hline 8 & 1905 & $\begin{array}{l}\text { Muhammad Basyuni Imran diangkat menjadi imam pembantu di } \\
\text { masjid Jami' Sambas. }\end{array}$ \\
\hline \multirow{2}{*}{9} & \multirow{2}{*}{1908} & $\begin{array}{l}\text { Raden M. Ariadiningrat diangkat menjadi kolektor pajak dalam } \\
\text { wilayah Kesultanan Sambas. }\end{array}$ \\
\hline & & $\begin{array}{l}\text { Muhammad Basyuni Imran melanjutkan pendidikan di al-Azhar } \\
\text { Cairo, Mesir }\end{array}$ \\
\hline 10 & 1910 & (1 Desember) sekolah Byzondere School didirikan. \\
\hline 11 & 1912 & $\begin{array}{l}\text { (20 September) Pemerintah Hindia Belanda diwakili W. Feyling, } \\
\text { Regeering Commisaris Pulau Borneo mengikat kontrak politik (korte } \\
\text { verklaring) dengan Sultan Muhammad Syafiuddin II. Berdasarkan } \\
\text { kontrak, Kesultanan Sambas menjadi sebuah landschap (zelfbestuur). } \\
\text { Sultan berhak menentukan hak dan kewajiban penduduk pribumi } \\
\text { dalam wilayahnya, serta orang-orang Eropa dan Timur Asing. Pribumi } \\
\text { tunduk pada kuasa dan hukum Sultan (hukum adat), sementara orang } \\
\text { Eropa dan Timur Asing tunduk pada hukum Barat (Belanda). }\end{array}$ \\
\hline \multirow{3}{*}{12} & \multirow{3}{*}{1913} & $\begin{array}{l}\text { Muhammad Basyuni Imran melanjutkan pendidikan di Dar al- } \\
\text { Dakwah wa al-Irsyad, Manyal Kairo. }\end{array}$ \\
\hline & & $\begin{array}{l}\text { (25 Agustus) Muhammad Basyuni Imran pulang dari Mesir ke } \\
\text { Sambas karena orang tuanya sakit keras. }\end{array}$ \\
\hline & & $\begin{array}{l}\text { (9 November) Sultan M. Syafiuddin melantik Muhammad Basyuni } \\
\text { Imran menjadi Maharaja Imam Sambas. }\end{array}$ \\
\hline 13 & 1914 & $\begin{array}{l}\text { Maharaja Imam M. Basyuni Imran menulis risalah Manhāl al- } \\
\text { Ghāribīn fi Iqamāt al-Jumu'ah bi dūn al-Arba'in (Pendapat Orang } \\
\text { yang Asing tentang Melaksanakan Shalat Jum'at Kurang dari Empat } \\
\text { Puluh Orang). Risalah ini tidak diterbitkan }\end{array}$ \\
\hline \multirow[b]{2}{*}{14} & \multirow[b]{2}{*}{1915} & $\begin{array}{l}\text { Sekolah Byzondere School diubah menjadi Hollands Inlandsche } \\
\text { School (HIS). }\end{array}$ \\
\hline & & $\begin{array}{l}\text { (17 Juli) Raden Mulia Ibrahim belajar di Sekolah OSVIA Serang } \\
\text { Banten, ditemani oleh Raden Muchsin Panji Anom dan Raden Abu } \\
\text { Bakar Panji Anom }\end{array}$ \\
\hline 15 & 1916 & Sultan M. Syafiuddin II menerima penghargaan bintang Commander in de \\
\hline
\end{tabular}




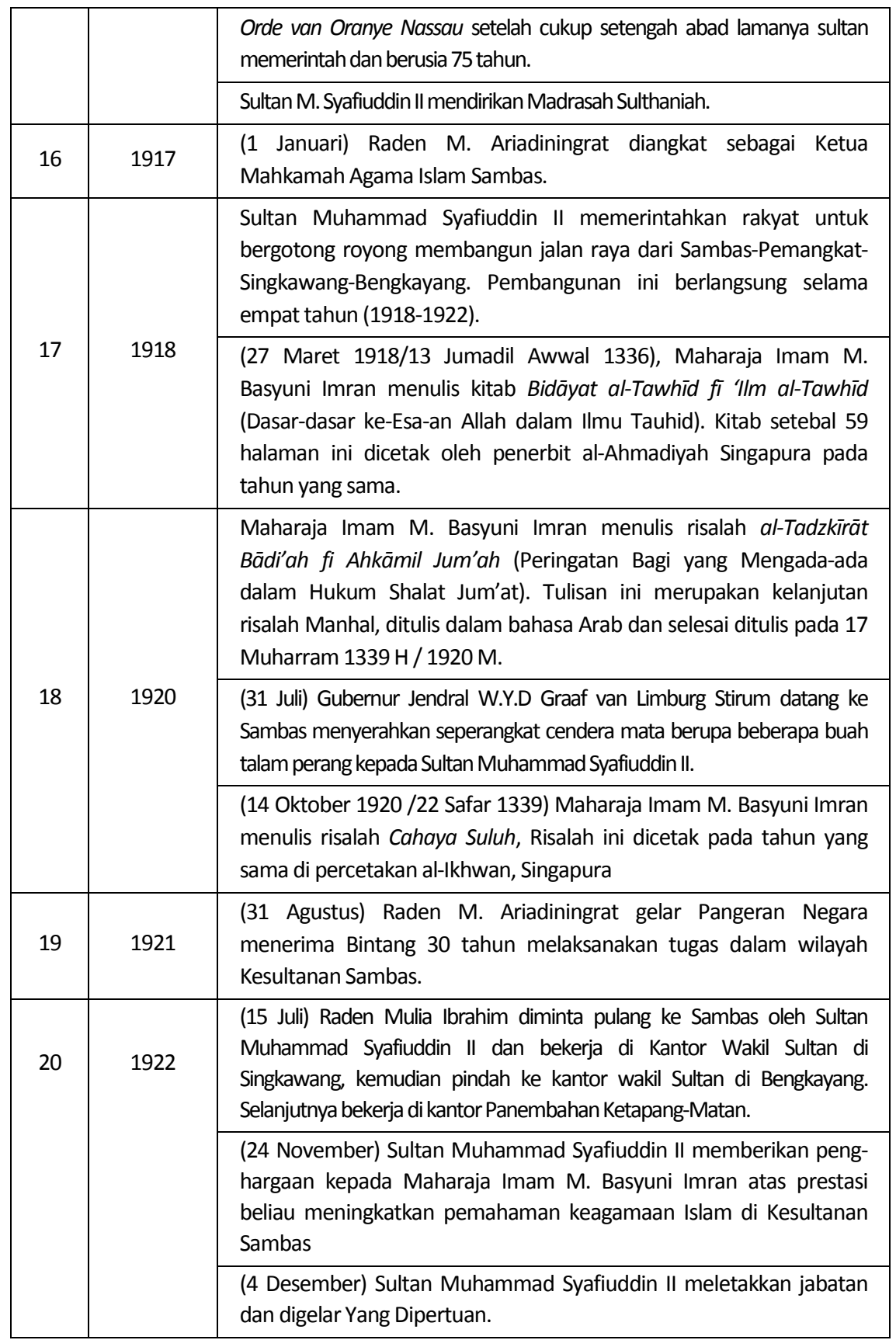




\begin{tabular}{|c|c|c|}
\hline & & $\begin{array}{l}\text { (4 Desember) Raden M. Ariadiningrat diangkat menjadi Sultan } \\
\text { Sambas ke-14 dengan gelar Sultan M. Ali Syafiuddin II }\end{array}$ \\
\hline & & $\begin{array}{l}\text { (4 Desember) Belanda mengikat kontrak politik dengan Sultan } \\
\text { Sambas. }\end{array}$ \\
\hline 21 & 1923 & $\begin{array}{l}\text { Sultan Muhammad Ali Syafiuddin II meminta rakyatnya bergotong } \\
\text { royong membangun terusan Segerunding, Kota Bangun, Sappo', dan } \\
\text { terusan Ketapang. }\end{array}$ \\
\hline 22 & 1924 & $\begin{array}{l}\text { (12 September = } 12 \text { Shafar } 1343 \text { ) hari Jumat pukul } 20.00 \text { Sultan M. } \\
\text { Syafiuddin wafat. }\end{array}$ \\
\hline 23 & 1925 & $\begin{array}{l}\text { Kitab Al-Nușūṣ wa 'I-Barāhin 'alā lqāmat al-Jum'ah bimā Dūn al- } \\
\text { Arba'in (Beberapa Dalil dan Argumentasi dalam Melaksanakan } \\
\text { Shalat Jum'at yang Kurang dari Empat Puluh Orang), karya Maharaja } \\
\text { Imam M. Basyuni Imran dicetak oleh percetakan al-Manar, Kairo. } \\
\text { Karya ini merupakan edisi bahasa Arab dari risalah Cahaya Suluh. }\end{array}$ \\
\hline & & $\begin{array}{l}\text { (9 Oktober = } 1 \text { Rabiul Awal 1345) Sultan M. Ali Syafiuddin II wafat } \\
\text { dalam usia } 54 \text { tahun. }\end{array}$ \\
\hline 24 & 1926 & $\begin{array}{l}\text { (10 Oktober) dibentuk Majelis Kesultanan yang melaksanakan tugas } \\
\text { Sultan Sambas, mengingat Sultan Muhammad Mulia Ibrahim masih } \\
\text { sangat muda. }\end{array}$ \\
\hline 25 & 1928 & $\begin{array}{l}\text { M. Basyuni Imran mengirim surat kepada Rasyid Ridha dengan } \\
\text { pertanyaan "mengapa kaum Muslimin mundur dan mengapa selain } \\
\text { mereka maju". }\end{array}$ \\
\hline 26 & 1930 & $\begin{array}{l}\text { (3 September } 1930 \text { /9 Rabiul Awwal 1349) Maharaja Imam Maharaja } \\
\text { Imam M. Basyuni Imran menulis kitab Tadzkī, Sabīl al-Najāh fi Tārik } \\
\text { al-Ṣalāh (Jalan Kelepasan pada Mengingati Orang yang } \\
\text { Meninggalkan Sembahyang). Kitab ini dicetak oleh percetakan al- } \\
\text { Ahmadiyah, Singapura, pada tahun } 1931 \text {. }\end{array}$ \\
\hline \multirow{4}{*}{27} & \multirow{4}{*}{1931} & $\begin{array}{l}\text { (18 Januari 1931/29 Sya'ban 1349). Maharaja Imam M. Basyuni } \\
\text { Imran menulis Kitab Khulasah Sirah al-Muhammadiyah. Khulasah } \\
\text { adalah kitab sejarah karangan Muhammad Rasyid Ridha. Basyuni } \\
\text { Imran menambahkan kata-kata Hakikat Seruan Islam pada judul } \\
\text { terjemahannya. Terjemahan setebal } 89 \text { halaman ini dicetak oleh } \\
\text { percetakan al-Ahmadiyah, Singapura. }\end{array}$ \\
\hline & & $\begin{array}{l}\text { (1 Mei) Belanda mengikat Kontrak Politik dengan Sultan Muhammad } \\
\text { Mulia Ibrahim. }\end{array}$ \\
\hline & & $\begin{array}{l}\text { (2 Mei) Raden Mulia Ibrahim bergelar Sultan Muhammad Mulia } \\
\text { Ibrahim Syafiuddin diangkat menjadi Sultan Sambas ke-15. }\end{array}$ \\
\hline & & $\begin{array}{l}\text { Situasi dan kondisi negeri Sambas mengalami masa krisis. Kondisi ini } \\
\text { berlangsung sampai tahun } 1933\end{array}$ \\
\hline
\end{tabular}




\begin{tabular}{|c|c|c|}
\hline 28 & 1933 & $\begin{array}{l}\text { Sultan Mulia M. Ibrahim membangun istana baru di atas istana yang } \\
\text { lama. }\end{array}$ \\
\hline 29 & 1934 & $\begin{array}{l}\text { (21 Januari 1934/5 Syawal 1352) Maharaja Imam M. Basyuni Imran } \\
\text { menulis kitab Irsyād al-Ghilmān fi Adab Tilāwat al-Qur'ān (Petunjuk } \\
\text { Praktis untuk anak tentang Adab Membaca al-Qur'an). Kitab ini } \\
\text { diterbitkan dan dicetak pada percetakan al-Ahmadiyah Singapura. }\end{array}$ \\
\hline \multirow[b]{3}{*}{30} & \multirow[b]{3}{*}{1935} & (6 Juli) istana baru ditempati. \\
\hline & & (15 Juli) istana baru diresmikan. \\
\hline & & $\begin{array}{l}\text { (18 oktober 1935/20 Rajab 1354) Maharaja Imam M. Basyuni Imran } \\
\text { menulis kitab Durūs al-Tawhīd (Pelajaran-pelajaran tentang Tauhid). } \\
\text { Kitab ini kemudian diterbitkan dan dicetak pada percetakan al- } \\
\text { Ahmadiyah Singapura. }\end{array}$ \\
\hline \multirow{3}{*}{31} & \multirow{3}{*}{1936} & $\begin{array}{l}\text { Dibentuk peradilan khusus golongan pribumi (Pengadilan Balai } \\
\text { Kanon, Pengadilan Balai Raja, dan Pengadilan Balai Bidai) }\end{array}$ \\
\hline & & $\begin{array}{l}\text { (19 April) perkumpulan Terbitoel Islam terbentuk atas prakarsa } \\
\text { Maharaja Imam Muhammad Basyuni Imran. }\end{array}$ \\
\hline & & $\begin{array}{l}\text { (5 Juli) Statuten (Anggaran Dasar) Perkumpulan Tarbiatoel Islam } \\
\text { disahkan dalam rapat umum anggota di gedung Sekolah Tarbiatoel } \\
\text { Islam Sambas }\end{array}$ \\
\hline 32 & 1937 & $\begin{array}{l}\text { Jembatan batu Lengkung Dua dan Tiga mulai dibangun oleh } \\
\text { kontraktor dari Jerman bernama Ir. Massink dibantu oleh Ir. Soecitro } \\
\text { dari bangsa Indonesia }\end{array}$ \\
\hline 33 & 1938 & $\begin{array}{l}\text { Kitab Daw' al-Misbāh fi Faskh al-Nikāh (Cahaya Lampu Untuk } \\
\text { Membatalkan Nikah), karya Maharaja Imam M. Basyuni Imran } \\
\text { dicetak di Penang, Malaysia }\end{array}$ \\
\hline 34 & & $\begin{array}{l}\text { Kitab Husn al-Jawāb 'an Isbāt al-Ahillah bi 'I-Hisāb (Molek Jawaban } \\
\text { tentang Menetapkan Awal Bulan Dengan Hitungan). karya Maharaja } \\
\text { Imam M. Basyuni Imran dicetak di Penang, Malaysia. }\end{array}$ \\
\hline \multirow[t]{4}{*}{35} & \multirow[t]{4}{*}{1943} & $\begin{array}{l}\text { Maharaja Imam M. Basyuni Imran menulis Kitāb al-Janāiz. Kitab kecil } \\
\text { ini ditulis di Sambas pada masa pemerintahan pendudukan Jepang. } \\
\text { (kalender Jepang: } 21 \text { Sigitsu 2603). }\end{array}$ \\
\hline & & $\begin{array}{l}\text { Sultan Muhammad Mulia Ibrahim ditangkap dan dibunuh di } \\
\text { Mandor, Landak }\end{array}$ \\
\hline & & $\begin{array}{l}\text { (25 Maret s.d. } 18 \text { oktober) Pemerintah Pendudukan Jepang } \\
\text { membentuk Majelis Kesultanan (Zitirijo Hiyogi Kai) untuk } \\
\text { melaksanakan tugas pemerintahan Kesultanan }\end{array}$ \\
\hline & & $\begin{array}{l}\text { ( } 23 \text { Oktober) organisasi perjuangan bernama Persatuan Bangsa } \\
\text { Indonesia Sambas (PERBIS) didirkan }\end{array}$ \\
\hline
\end{tabular}




\begin{tabular}{|c|c|c|}
\hline & & $\begin{array}{l}\text { ( } 25 \text { Oktober) Bendera Merah Putih berkibar di tiap rumah penduduk } \\
\text { di Kampung Banjar, Pemangkat }\end{array}$ \\
\hline & & $\begin{array}{l}\text { (27 Oktober) pejuang Sambas bernama Tabrani Ahmad gugur } \\
\text { ditembak Balanda dalam mempertahankan bendera merah putih. }\end{array}$ \\
\hline & & $\begin{array}{l}\text { (27 Oktober) Peristiwa pengibaran bendera Merah Putih di Istana } \\
\text { Sambas }\end{array}$ \\
\hline & & $\begin{array}{l}\text { (11 November) PERMI (Persatuan Muslim Indonesia) Sambas } \\
\text { didirikan. Organisasi ini diprakarsai oleh pejuang Sambas. }\end{array}$ \\
\hline \multirow{4}{*}{36} & \multirow{4}{*}{1946} & BPIKB (Barisan Pemberontak Indonesia Kalimantan Barat) didirikan \\
\hline & & $\begin{array}{l}\text { (20 Februari) Gubernur Jenderal Belanda DR. H.J. van Mook melalui } \\
\text { perantaraan Sultan Hamid II membentuk dan melantik sebuah } \\
\text { Majelis Kesultanan Sambas }\end{array}$ \\
\hline & & $\begin{array}{l}\text { (16 April) Berdirilah Organisasi PORI (Persatuan Olahraga Republik } \\
\text { Indonesia) }\end{array}$ \\
\hline & & $\begin{array}{l}\text { Muhammad Basyuni Imran diangkat sebagai Advisur Commissi van Bestuur } \\
\text { Sambas. Beliau menjabat selama } 5 \text { tahun (1946-1951). }\end{array}$ \\
\hline 37 & 1949 & $\begin{array}{l}\text { (10 Januari) penyerangan terhadap tangsi Belanda diserang oleh } \\
\text { para pejuang Sambas. }\end{array}$ \\
\hline 38 & 1950 & $\begin{array}{l}\text { Daerah bekas Kesultanan Sambas mulai dipimpin oleh seorang } \\
\text { bupati. }\end{array}$ \\
\hline 39 & 1952 & $\begin{array}{l}\text { Maharaja Imam Basyuni Imran diangkat Menteri Agama RI sebagai } \\
\text { penghulu muda KUA Kabupaten Sambas. }\end{array}$ \\
\hline 40 & 1955 & $\begin{array}{l}\text { Muhmmad Basyuni Imran menjadi anggota Konstituante mewakili } \\
\text { Kalbar dari Partai Masyumi. }\end{array}$ \\
\hline 41 & 1958 & $\begin{array}{l}\text { (22 Mei) Kabupaten Sambas melaksanakan Pemilu daerah yang } \\
\text { pertama. }\end{array}$ \\
\hline 42 & 1966 & $\begin{array}{l}\text { Maharaja Imam M. Basyuni Imran diangkat sebagai Ketua } \\
\text { Pengadilan Agama di Sambas. Beliau menjabat selama } 9 \text { tahun } \\
\text { (1966-1975). }\end{array}$ \\
\hline 43 & 1967 & $\begin{array}{l}\text { Maharaja Imam M. Basyuni Imran diangkat sebagai Pimpinan } \\
\text { Kullijatul Muballighin Sambas. }\end{array}$ \\
\hline 44 & 1976 & $\begin{array}{l}\text { (22 Juli) Maharaja Imam M. Basyuni Imran wafat, dan dimakamkan } \\
\text { di Kampung Dagang Timur. }\end{array}$ \\
\hline
\end{tabular}




\section{Metode Pendidikan dan Prilaku Keberagamaan}

Gerakan H. M. Basyuni Imran di bidang pendidikan terlihat jelas ketika beliau diangkat oleh Sultan menjadi pengawas di Madrasah al-Sultaniyah (1919-1935), ketika itu lembaga pendidikan ini masih berada di bawah otoritas Sultan Sambas. Namun gerakan itu baru mengambil wujudnya yang nyata ketika ia mendirikan Perkumpulan Tarbiatoel Islam dan sekaligus mendirikan sekolah Tarbiatoel Islam pada tahun 1936.

Ide memodernisir Madrasah al-Sultaniyah menjadi sekolah Tarbiatoel Islam didorong oleh situasi ketika pemerintah kolonial Belanda berencana akan membubarkan HIS menyusul krisis ekonomi di Sambas pada 1933. Sedangkan antusiasme putra-putri Sambas untuk belajar bahasa Belanda dan pengetahuan umum cukup besar. Satu-satunya sekolah umum yang ada pada waktu itu hanya sekolah misi milik Katolik. Berdirinya sekolah misi di Sambas ini mendorong Basyuni Imran bergerak cepat karena sadar bahwa adanya sekolah umum yang menarik anak-anak dari lapisan masyarakat atas dan menengah, akan berdampak merugikan pendidikan Islam yang sudah ada pada waktu itu. Untuk menyikapi kondisi ini, Basyuni Imran mengadakan pertemuan dengan beberapa tokoh di Sambas seperti dr. Syahrial dan Ali Imran (seorang guru HIS). Dalam pertemuan itu diputuskan madrasah alSultaniyah akan dikelola dengan pola pembelajaran seperti sekolah umum Belanda, namun tetap mempertahankan ciri pendidikan Islam.

Untuk mengelola Madrasah al-Sultaniyah secara profesional, maka dibentuklah perkumpulan Tarbiatoel Islam pada tahun 1936. Perkumpulan ini memiliki motto, "Nusa dan Bangsa tidak akan lekas majunya jika tidak memiliki perguruan bangsanya sendiri”. Schakelschool itu kemudian diberi nama Sekolah Tarbiatoel Islam (Pangeran Tumenggung Jaya Kusuma, 1951: 78).

Didirikannya perkumpulan Tarbiatoel Islam dengan sekolah-sekolahnya bertujuan untuk dapat merealisasikan gagasan-gagasan pembaruan dalam pemikiran Basyuni Imran. Sisi-sisi pembaruan ini tampak dalam lembagalembaga pendidikan ia dirikan dan atau ia pimpin. Berdasarkan Statuten (1936) perkumpulan Tarbiatoel Islam bertujuan: "memajukan dan menggembirakan (menggemarkan) pengajaran dan pelajaran Agama Islam dalam 
kerajaan Sambas serta memajukan cara kehidupan sepanjang kemauan agama Islam kepada anggota-anggotanya (lid-lidnya)". Adapun struktur kurikulum yang ada pada saat itu dapat dilihat pada tabel berikut:

Tabel 2.

Mata Pelajaran Madrasah al-Sultaniyah

\begin{tabular}{|c|c|c|c|}
\hline No. & Mata Pelajaran & Kitab Rujukan & Guru \\
\hline 1 & Tauhid & $\begin{array}{l}\text { Al-Islām Sharīah wa } \\
\text { 'Aqīdah } \\
\text { al-Jawāhir al-Kalāmiyyah }\end{array}$ & H. M. Basyuni Imran \\
\hline 2 & Hadits & $\begin{array}{l}\text { Șahīh Bukhāriy } \\
\text { Șahīh Muslim }\end{array}$ & H. Muh. Djabir \\
\hline 3 & Fikih & $\begin{array}{l}\text { Fath al-Qarīb } \\
\text { Husn al- Hamídiyyah }\end{array}$ & H. Abdurrahman Hamid \\
\hline 4 & $\begin{array}{l}\text { Bahasa Arab } \\
1 \& 2\end{array}$ & $\begin{array}{l}\text { Qawā'id al- Lughah al- } \\
\text { 'Arabiyah } \\
\text { An-Nahww al- Wadhīh }\end{array}$ & $\begin{array}{l}\text { 1. Muh. Sirri; } \\
\text { 2. H. Muh. Arif }\end{array}$ \\
\hline 5 & Tarikh & $\begin{array}{l}\text { Tarīkh al-Islām } \\
\text { Al-Hayyat (1-5) }\end{array}$ & Abdullah Ali \\
\hline 6 & Berhitung & - & Abdullah Ali \\
\hline 7 & $\begin{array}{l}\text { Membaca } \\
\text { Huruf Latin }\end{array}$ & - & Raden Abdul Mutalib \\
\hline 8 & $\begin{array}{l}\text { Menulis } \\
\text { Huruf Latin }\end{array}$ & - & Raden Abdul Mutalib \\
\hline
\end{tabular}

Sumber: Wawancara H. Murad Kasim (7/1/2002)

Pada perkembangan selanjutnya tenaga pengajar sekolah Tarbiatoel Islam sebagian besar adalah lulusan HIK (Holland Inlandsche Kweekschool) yang berasal dari Bandung dan Yogyakarta, dan sebagian lagi dari berasal dari madrasah al-Juneid Singapura.

Kebijakan mendatangkan guru-guru dari luar antara lain dilatarbelakangi oleh kepentingan sekolah Tarbiatoel Islam akan tenaga-tenaga pengajar yang memiliki kualifikasi tinggi. Di sisi lain kebijakan ini juga berarti telah memasukkan pembaruan yang dibawa oleh guru-guru ini ketika mereka masih berada di pulau Jawa dan Sumatera yang dipandang sebagai 
daerah yang paling maju keilmuan dan keagamaannya di Nusantara. Dengan demikian, maka secara langsung Basyuni Imran mengunakan sistem ganda dalam penetapan struktur kurikulumnya yakni dengan mengadopsi pendidikan Belanda dan pendidikan klasikal sebelumnya. Adapun struktur kurikulum dan nama-nam guru yang terlibat di dalamnya antara lain:

Tabel 3.

Materi Pembelajaran Sekolah Tarbatoel Islam

\begin{tabular}{|c|l|l|}
\hline No. & \multicolumn{1}{|c|}{ Materi } & \multicolumn{1}{c|}{ Guru } \\
\hline 1 & Sejarah (Geschiedenisch) & Mursyid Idris \\
\hline 2 & Berhitung (Rekenekunde) & Mursyid Idris \\
\hline 3 & Ilmu Alam (Natuurkunde) & Mursyid Idris \\
\hline 4 & $\begin{array}{l}\text { Ilmu Tumbuhan } \\
\text { (Palntkunde) }\end{array}$ & Mursyid Idris \\
\hline 5 & Ilmu Hewan (Oirkunde) & Mursyid Idris \\
\hline 6 & $\begin{array}{l}\text { Ilmu Manusia } \\
\text { (Manskunde) }\end{array}$ & Sofyan Ahmad \\
\hline 7 & $\begin{array}{l}\text { Bahasa Belanda } \\
\text { (Nederlandsche Taal) }\end{array}$ & Sofyan Ahmad \\
\hline 8 & Bahasa Melayu & Ariani Hardigaluh \\
\hline 9 & Menyanyi (Singen) & Raden Abdul Mutalib \\
\hline 10 & Bahasa Arab & Abdurrahman Hamid \\
\hline 11 & Tauhid & Abdurrahman Hamid \\
\hline 12 & Fikih & Abdurrahman Hamid \\
\hline
\end{tabular}

Sejak perubahan madrasah al-Sultaniyah menjadi sekolah Tarbiatoel Islam, pelajaran yang bersifat nasionalisme pun mulai diajarkan. Pendidikan Tarbiatoel Islam mulai diarahkan untuk menjadi wahana pengembangan wawasan kebangsaan. Menurut H.A.R. Tilaar (1995: 35) pada masa kebangkitan nasional, pendidikan menyatu dengan gerakan kebangsaan. Ketika kakitangan pemerintah Kolonial mulai menindas gerakan kebangsaan, pendidikan merupakan sarana paling ampuh untuk menyalurkan cita-cita kemerdekaan.

Semangat kebangkitan ini juga ternyata ditangkap oleh sekolah Tarbiatoel Islam. Kondisi ini mendorong Tarbiatoel Islam menjadi lembaga 
pendidikan yang lebih terbuka. Pendidikan kebangsaan yang dikembangkan oleh Tarbiatoel Islam melahirkan banyak kader. Beberapa orang guru Tarbiatoel Islam adalah anggota partai politik dan aktivis pergerakan pada waktu itu. Misalnya saja Mursyid Idris adalah anggota Partai Indonesia Raya (Parindra) Sambas dan Izzuddin Zubir adalah aktivis Persatuan Muslimin Indonesia (PERMI). Demikian juga dengan Hamidi Abdurrahman yang aktif di Persatuan Bangsa Indonesia Sambas (PERBIS).

\section{F. Kesimpulan}

Dalam perspektif melihat sejarah sebagai sebuah kajian keilmuan. Hal ini tidak terlepas dari unsur subjektivitas latar belakang penulis dalam menginterpretasikan peristiwa ke dalam untaian bahasa. Hal ini yang kemudian menjadi kesimpulan sisi edukatif dari penetrasi suatu pemerintahan yang tak dapat dipungkiri memiliki pengaruh signifikan terhadap perkembangan sosial, budaya, ekonomi dan pendidikan di wilayah otoritasnya. Hal ini juga yang terjadi di Kerajaan Sambas, sebuah imperium dari konstruksi masyarakat feodal di wilayah utara Kalimantan Barat.

Kekuasaan kerajaan yang memiliki peran strategis dalam politik dan militer secara tidak langsung mempengaruhi ketercepatan proses penyebaran dan asimilasi keilmuan. Namun hal ini tentu tidak hanya dapat dilakukan dengan tekanan tersebut yang malah menimbulkan konflik sosial, melainkan pula perlu ditekankan kebijaksanaan, kewibawaan dan intelektualitas yang tinggi. Inilah peta kekuatan raja-raja Sambas yang melakukan penyebaran Islam di kawasan kerajaannya.[w] 


\section{BIBLIOGRAFI}

Azra, Azyumardi, Jaringan Ulama Timur Tengah dan Kepulauan Nusantara Abad XVII dan XVIII: Melacak Akar-akar Pembaharuan Pemikiran Islam di Indonesia, Bandung: Mizan, 1998.

Clifford Greetz, The Religion of Java, New York: Free Press, 1960.

De Boer, T. J., History of Philosophy in Islam, New York: Dover Publications, 1970.

Hermansyah, Sejarah Kerajaan Sambas, Pontianak: STAIN Press, 2003.

Israeli, Raphael, The Crescent in The East, Islam in Asia Major. USA: Curzon PressLondon \& Humanities Press-NJ, 1982.

MUI, Sejarah Umat Islam Indonesia, Jakarta: Bulan Bintang, 1991.

Meuraxa, D., Sejarah Masuknya Islam ke Bandar Barus Sumatera Utara, Medan Sastrawan, 1973.

Musa, Pabali, Sejarah Kesultanan Sambas Kalimantan Barat (Kajian Naskah Asal Raja-Raja dan Silsilah Raja Sambas, Pontianak: STAIN Press, 2003.

Mustajab, Mohd. Sarim, Warisan Budaya Sabah Etnisiti dan Masyarakat, Bangi Selangor Darul Ehsan Kuala Lumpur: Universiti Kebangsaan Malaysia, 2004.

Musa, Pabali, Sejarah Kesultanan Sambas Kalimantan Barat (Kajian Naskah Asal Raja-Raja dan Silsilah Raja Sambas, Pontianak: STAIN Press, 2003.

Mustajab, Mohd. Sarim, Warisan Budaya Sabah Etnisiti dan Masyarakat, Bangi Selangor Darul Ehsan Kuala Lumpur: Universiti Kebangsaan Malaysia, 2004.

Nasution, Harun, Islam Ditinjau dari Berbagai Aspeknya, Jakarta: UI Press, 1985.

Nata, Abuddin, Sejarah Kebudayaan Islam-II. Jakarta: Direktorat jendral Pembinaan Kelembagaan Agama Islam dan Universitas Terbuka, 1996. 